\title{
Presencia serológica de Besnoitia besnoiti, Toxoplasma gondii, Coxiella burnetii y Chlamydia abortus en hatos bovinos de Costa Rica
}

Daisy Fallas-Elizondo ${ }^{1} \bowtie$, Jorge Chacón Calderón², Juan José Romero-Zuñiga ${ }^{1}$, Gaby Dolz $^{1,2}$

1 Posgrado Regional en Ciencias Veterinarias Tropicales (PCVET), Universidad Nacional (UNA), Campus Pbro. Benjamín Núñez, Barreal Heredia, Costa Rica. Email: daisy.fallas.elizondo@est.una.ac.cr, juan.romero.zuñiga@una.cr, gaby.dolz.wiedner@una.cr

2 Escuela de Medicina Veterinaria, UNA, Campus Pbro. Benjamín Núñez, Barreal Heredia, Costa Rica. Email: jorge.chacon.calderon@una.cr, gaby.dolz.wiedner@una.cr

Los protozoarios Besnoitia besnoiti y Toxoplasma gondii, y las bacterias Coxiella burnetii y Chlamydia abortus generan problemas económicos en la ganadería debido a que ocasionan abortos, aumentada mortalidad, pérdidas de peso, infertilidad y baja producción láctea, además del riesgo zoonótico que representa la mayoría de estos agentes. El objetivo del presente estudio fue determinar la presencia de anticuerpos específicos contra B. besnoiti, T. gondii, C. burnetii y C. abortus en bovinos seleccionados de Costa Rica. Durante el año 2015-2016 se recolectaron 92 muestras de suero bovino, provenientes de 6 provincias de Costa Rica, 48 sueros de vacas lecheras con problemas reproductivos (seronegativas a Brucella abortus y Neospora caninum) y 44 sueros de toros de monta, presentados para el control del virus de la leucosis bovina enzoótica. Los sueros se analizaron mediante ensayos inmunoenzimáticos comerciales. Se detectó una seropositividad de $31.5 \%$ (29/92) para B. besnoiti, en hembras un $20.8 \%$ (10/48) y en machos un $43.1 \%$ (19/44), una seropositividad de $36.9 \%$ (34/92) para T. gondii, en hembras un $45.8 \%$ (22/48) y machos un $27.2 \%(12 / 44)$. Para C. burnetii se determinó también una positividad de $36.9 \%$ (34/92) siendo un $43.7 \%$ (21/48) de hembras y un $29.5 \%$ (13/44) de machos seropositivos. Finalmente se encontró un $58.6 \%$ (54/92) de animales seropositivos para C. abortus, entre estos, un 35.4 $\%$ (17/48) de hembras y un $84 \%$ (37/44) de machos. Las muestras positivas se distribuyeron ampliamente entre las provincias muestreadas, de igual forma entre los tres tipos productivos: leche, carne y doble propósito. Este representa el primer reporte sobre la presencia serológica de anticuerpos contra $B$. besnoiti, T. gondii, C. burnetii y C. abortus en Costa Rica. Se recomienda confirmar la presencia de los agentes mediante técnicas moleculares y determinar la prevalencia y las pérdidas económicas que pudieran estar ocasionando. Además, se aconseja alertar a la población sobre el potencial zoonótico de T. gondii, C. burnetii y C. abortus.

Autor para correspondencia Daisy Fallas-Elizondo: daisy.fallas.elizondo@est.una.ac.cr, daifallas@gmail.com 